JOURNAL OF MIDWIFERY CARE :

VOL. 01 NO. 02, JUNI 2021

DOI: $\underline{10.34305 / j m c . v 1 i 02.266}$
Ciptaan disebarluaskan di bawah

Lisensi Creative Commons Atribusi-

NonKomersial-BerbagiSerupa 4.0

Internasional.

\title{
HUBUNGAN STATUS GIZI DENGAN KEJADIAN ANEMIA PADA REMAJA PUTRI DI SMP NEGERI 2 GARAWANGI KABUPATEN KUNINGAN
}

\author{
${ }^{1}$ Siti Nunung Nurjannah, ${ }^{2}$ Ega Anggita Putri \\ Sekolah Tinggi Ilmu Kesehatan Kuningan \\ sitinunung.nurjannah@gmail.com
}

\begin{abstract}
Abstrak
Status gizi merupakan salah satu faktor penyebab kejadian anemia pada remaja putri. Anemia pada remaja putri sampai saat ini masih cukup tinggi, prevalensi anemia didunia berkisar $40-88 \%$. Sebanyak $21,7 \%$ penduduk Indonesia terkena anemia dengan penderita anemia berumur 15-24 tahun sebesar 18,4\%. Penelitian ini bertunjuan untuk mengetahui hubungan status gizi dengan kejadian anemia pada remaja putri. Metode penelitian ini menggunakan penelitian analitik dengan menggunakan rancangan cross sectional, populasi dalam penelitian ini 110 responden dengan menggunakan teknik pengambilan sampel total sampling. Instrument yang digunakan lembar checklist, uji analisa yang digunakan adalah uji Chi-Square. Hasil analisis univariat, status gizi kurus $35,5 \%$, status gizi normal $57,3 \%$, status gizi gemuk 7,3\%, remaja anemia $82 \%$, dan remaja tidak anemia $28 \%$. Sedangkan analisis bivariat, penelitian menunjukkan terdapat hubungan yang signifikan antara status gizi dengan kejadian anemia dengan nilai $\mathrm{p}$ value $=0,000$. Pada penelitian ini, terdapat hubungan antara status gizi dengan kejadian anemia pada remaja putri SMP Negeri 2 Garawangi Kabupaten Kuningan . Bagi remaja putri diharapkan dapat memperbaiki pola gizi sebagai pengganti zat besi sehingga dapat mencegah kejadian anemia lebih dini dan bagi institusi pendidikan diharapkan dapat melakukan kerjasama dengan pihak puskesmas setempat atau tenaga kesehatan untuk dilakukan bimbingan atau penyuluhan mengenai pemenuhan nutrisi pada remaja putri dalam upaya pencegahan anemia.
\end{abstract}

Kata kunci : Status gizi, Anemia, Remaja putri 
JOURNAL OF MIDWIFERY CARE :

VOL. 01 NO. 02, JUNI 2021

DOI: $\underline{10.34305 / \mathrm{jmc} . \mathrm{v} 1 \mathrm{i} 02.266}$

\section{Pendahuluan}

Keberhasilan pembangunan nasional suatu bangsa ditentukan oleh ketersediaan Sumber Daya Manusia (SDM) yang berkualitas. Namun SDM yang masih jauh dari harapan yang diinginkan, karena masih banyak mengalami masalah gizi, salah satunya adalah anemia.

Anemia dapat menyerang siapa saja namun paling sering menyerang wanita usia subur khususnya remaja putri. Remaja putri masih menjadi masalah kesehatan masyarakat. Seharusnya periode remaja putri merupakan fase penting sebagai persiapan menjadi calon ibu sehingga dituntut dalam pemenuhan gizi.

Menurut data Riset Kesehatan Dasar Republik Indonesia (Riskesdas, 2013), kelompok umur 13-15 tahun penilaian status gizi berdasarkan IMT, prevalensi nasional kurus pada remaja umur 13-15 tahun adalah $11,1 \%$ terdiri dari 3,3\% sangat kurus dan 7,8\% kurus. Dan berdasarkan data (Dinas Kesehatan Provisi Jawa Barat, 2016), Prevalensi kurus pada remaja umur 16-18 tahun secara umum sebesar $9,1 \%(1,4 \%$ sangat kurus dan $7,7 \%$ kurus). Kabupaten Kuningan memiliki prevalensi kurus
Ciptaan disebarluaskan di bawah

Lisensi Creative Commons Atribusi-

NonKomersial-BerbagiSerupa 4.0

Internasional.

tertinggi kedua $(11,1 \%)$

Anemia adalah suatu keadaan dimana rendahnya konsentrasi hemoglobin $(\mathrm{Hb})$ berdasarkan nilai ambang batas (referensi) yang disebabkan oleh rendahnya produksi sel darah merah (eritrosit) dan Hb. Defisiensi Fe berperan besar dalam kejadian anemia, namun defisiensi zat lainnya, kondisi non gizi, dan kelainan genetik (herediter) juga memerankan peran terhadap anemia (Departemen Gizi Dan Kesehatan Masyarakat, 2012). Anemia pada remaja putri sampai saat ini masih cukup tinggi, menurut (WHO, 2013), prevalensi anemia dunia berkisar 40-88\%. Berdasarkan Riskesdas (2013) sebanyak 21,7\% penduduk Indonesia terkena anemia dengan penderita anemia berumur 15- 24 tahun sebesar $18,4 \%$.

Berdasarkan hasil studi pendahuluan, UPTD Puskesmas Garawangi telah melakukan sosialisasi pada bulan Maret kepada 91 remaja kelas IX SMP Negeri 2 Garawangi Angkatan $\mathrm{Ke}-14$ yang dilakukan pemeriksaanHb dengan hasil sebagai berikut, hanya 5 remaja $(5,5 \%)$ yang memiliki Hb normal, 76 remaja $(83,5 \%)$ mengalami anemia ringan sekali, 9 remaja $(9,9 \%)$ mengalami anemia ringan, dan 1 remaja $(1,1 \%)$ 
JOURNAL OF MIDWIFERY CARE :

VOL. 01 NO. 02, JUNI 2021

DOI: $\underline{10.34305 / j m c . v 1 i 02.266}$

mengalami anemia sedang.

Pemeriksaan ini merupakan upaya

Pemerintah Dinas Kesehatan Kabupaten

Kuningan dengan melaksanakan program sosialisasi untuk pencegahan anemia pada remaja yaitu dengan cara penyuluhan dan pemberian tablet tambah darah ke setiap sekolah-sekolah di Kabupaten Kuningan. Berdasarkan latar belakang di atas, peneliti tertarik untuk melakukan penelitian "Hubungan Status Gizi dengan Kejadian Anemia pada Remaja Putri’.

\section{Metode}

Penelitian ini menggunakan jenis penelitian kantitatif menggunakan metode
Ciptaan disebarluaskan di bawah

Lisensi Creative Commons Atribusi-

NonKomersial-BerbagiSerupa 4.0

Internasional.

penelitian analitik dengan studi korelasi. Rancangan yang digunakan yaitu pendekatan cross sectional. Populasi dalam penelitian ini adalah seluruh siswi kelas IX SMP Negeri 2 Garawangi Angkatan Ke-15 Kabupaten Kuningan yaitu sebanyak 110 responden. Sampel yang digunakan yaitu total sampling yaitu 110 responden. Variabel penelitian ini terdiri dari variabel bebas dan variabel terikat. Variabel bebasnya adalah status gizi. Sedangkan variabel terikatnya adalah kejadian anemia. Instrument yang digunakan yaitu timbangan berat badan, pengukur tinggi badan, $\mathrm{Hb}$ Elektrik dan lembar cheklist.

Hasil

Analisis Univariat

Tabel 1. Distribusi Frekuensi Status Gizi dan Hb Pada Remaja Putri di SMP Negeri 2 Garawangi Kabupaten Kuningan

\begin{tabular}{ccc}
\hline Variabel & Frekuensi & Persentase (\%) \\
\hline Status Gizi & 39 & 35.5 \\
Kurus & 63 & 57.3 \\
Normal & 8 & 7.3 \\
Gemuk & 110 & 100 \\
Total & & \\
Hb & 82 & 74.5 \\
Anemia & 28 & 25.5 \\
Tidak Anemia & 110 & 100 \\
Total &
\end{tabular}

Berdasarkan Tabel 1 dapat diketahui bahwa dari 110 remaja putri sebagian besar memiliki status gizi normal yaitu sebanyak 63 remaja $(57,3 \%)$. Selain itu, dapat diketahui bahwa dari 110 remaja putri sebagian besar mengalami anemia yaitu sebanyak 82 remaja $(74,5 \%)$. 
JOURNAL OF MIDWIFERY CARE :

VOL. 01 NO. 02, JUNI 2021

DOI: $10.34305 / j m c . v 1 i 02.266$
Ciptaan disebarluaskan di bawah

Lisensi Creative Commons Atribusi-

NonKomersial-BerbagiSerupa 4.0

Internasional.

\section{Analisis Bivariat}

Tabel 2. Hubungan Status Gizi Dengan Kejadian Anemia pada Remaja Putri di SMP Negeri 2 Garawangi Kabupaten Kuningan

\begin{tabular}{|c|c|c|c|c|c|c|c|}
\hline \multirow{3}{*}{ Status Gizi } & \multicolumn{4}{|c|}{ Kejadian Anemia } & & & \multirow{3}{*}{$P$ value } \\
\hline & \multicolumn{2}{|c|}{ Anemia } & \multicolumn{2}{|c|}{ Tidak Anemia } & \multicolumn{2}{|c|}{ Total } & \\
\hline & $\mathbf{F}$ & $\%$ & $\mathbf{F}$ & $\%$ & $\mathbf{F}$ & $\%$ & \\
\hline Kurus & 39 & 100.0 & 0 & 0.0 & 39 & 100 & \\
\hline Normal & 37 & 58.7 & 26 & 41.3 & 63 & 100 & \\
\hline Gemuk & 6 & 75.0 & 2 & 25.0 & 8 & 100 & 0.000 \\
\hline Total & 82 & 74.5 & 28 & 25.5 & 110 & 100 & \\
\hline
\end{tabular}

Sumber: Hasil Penelitian

Berdasarkan Tabel 2 dapat diketahui bahwa seluruh remaja putri dengan status gizi kurus mengalami anemia yaitu 39 remaja (100\%), 63 remaja putri dengan status gizi normal mengalami anemia sebanyak 37 remaja $(58,7 \%)$ dan 8 remaja putri dengan status gemuk mengalami anemia sebanyak 6 remaja (75\%).

Berdasarkan hasil uji statistik $p$ value $=0,000$, sehingga dapat disimpulkan bahwa terdapat hubungan yang bermakna antara status gizi dengan kejadian anemia pada remaja putri di SMP Negeri 2 Garawangi Kabupaten Kuningan

\section{Pembahasan}

\section{Analisis Univariat}

Gambaran Status Gizi Remaja Putri di SMP Negeri 2 Garawangi Kabupaten Kuningan diketahui bahwa dari 110 remaja putri sebagian besar memiliki status gizi normal yaitu sebanyak 63 remaja $(57,3 \%)$.
Status gizi adalah ukuran mengenai kondisi tubuh seseorang yang dapat dilihat dari makanan yang dikonsumsi dan penggunaan zat-zat dalam tubuh. Status gizi dibagi menjadi tiga kategori yaitu status gizi kurang, gizi baik/normal dan gizi lebih (Almatsier, 2009). Pola makan yang salah juga menjadi penyebab kebutuhan gizi remaja kurang sehingga status gizi menjadi kurang. Sebagai contoh melakukan diet yang salah karena takut mengalami kegemukan. Hal ini dikarenakan banyak remaja putri menganggap dirinya kelebihan berat badan atau mudah menjadi gemuk sehingga sering diet dengan cara yang kurang benar seperti membatasi atau mengurangi frekuensi makan dan jumlah makan (Proverawati, 2009).

Asupan nutrisi pada remaja sangat berpengaruh penting karena nutrisi merupakan salah satu faktor yang mempengaruhi terjadinya anemia, dan 
JOURNAL OF MIDWIFERY CARE :

VOL. 01 NO. 02, JUNI 2021

DOI: $\underline{10.34305 / \mathrm{jmc} . \mathrm{v} 1 \mathrm{i} 02.266}$

remaja yang sudah menderita anemia mempengaruhi pola aktivitas dan konsentrasi belajar.

Gambaran Anemia pada Remaja Putri di SMP Negeri 2 Garawangi Kabupaten Kuningan dapat diketahui bahwa dari 110 remaja putri sebagian besar mengalami anemia yaitu sebanyak 82 remaja (74,5\%). Hal ini menunjukan bahwa kejadian anemia pada remaja putri masih tinggi.

Selain kekurangan gizi anemia juga dapat disebabkan oleh pola menstruasi, dalam penelitian ini peneliti juga menggali data pola menstruasi pada responden, ditemukan rata-rata dari lama menstruasi adalah sekitar 7 hari $(6,83)$ dengan nilai terendah yaitu 4 hari dan nilai tertinggi yaitu 10 hari. Oleh karena itu, pada remaja putri dengan lama menstruasi yang lebih panjang pengeluaran darah yang dialami cenderung lebih banyak dan ketersediaan zat besi pun berkurang yang akhirnya menyebabkan kadar hemoglobin menurun. Hal ini sesuai dengan teori yang dikemukakan oleh Manuaba (2010), Wanita memerlukan zat besi lebih tinggi dari laki - laki karena terjadi mentruasi dengan perdarahan sebanyak 50 80 cc setiap bulan dan kehilangan zat besi sebanyak 30 - $40 \mathrm{mg}$. kehilangan darah inilah yang menyebabkan kejadian anemia.
Ciptaan disebarluaskan di bawah

Lisensi Creative Commons Atribusi-

NonKomersial-BerbagiSerupa 4.0

Internasional.

\section{Analisis Bivariat}

Hubungan Status Gizi Dengan Kejadian Anemia pada Remaja Putri di SMP Negeri 2 Garawangi Kabupaten Kuningan . Berdasarkan hasil uji statistik dengan menggunakan uji korelasi Chi-Square pada program computer diperoleh $\mathrm{p}$ value $=0,000$ yaitu kurang dari 0,05, sehingga dapat disimpulkan terdapat hubungan yang bermakna antara status gizi dengan kejadian anemia pada remaja putri di SMP Negeri 2 Garawangi Kabupaten Kuningan .

Responden dengan status gizi kurus, semuanya mengalami anemia yaitu sebanyak 39 remaja (100\%). Hal ini menunjukan bahwa status gizi sangat berpengaruh terhadap kejadian anemia. Sesuai dengan teori yang dikemukakan oleh (Almatsier, 2009), bahwa status gizi kurang berarti bahwa zat-zat gizi penting salah satunya adalah zat besi tidak dapat dipenuhi dengan baik.

Responden dengan status gizi normal mengalami anemia sebanyak 37 remaja $(58,7 \%)$ dan 26 remaja $(41,3 \%)$ tidak mengalami anemia. Hal ini menunjukan bahwa status gizi menjadi salah satu faktor yang dapat menyebabkan anemia. Dalam penelitian ini peneliti juga menggali data pola menstruasi pada responden, ditemukan rata-rata dari lama menstruasi adalah sekitar 
JOURNAL OF MIDWIFERY CARE :

VOL. 01 NO. 02, JUNI 2021

DOI: $10.34305 / j m c . v 1 \mathrm{i} 02.266$

7 hari $(6,83)$ dengan nilai terendah yaitu 4 hari dan nilai tertinggi yaitu 10 hari. Oleh karena itu, faktor lain penyebab anemia adalah pola menstruasi. Hal ini sesuai dengan teori yang dikemukakan oleh Arisman (2014) yang menyatakan bahwa remaja putri yang sudah mengalami menstruasi beresiko terjadi anemia defisiensi zat besi, karena jumlah darah yang hilang selama satu periode haid berkisar 2025 cc, jumlah ini menggambarkan kehilangan zat besi sebesar 12,5-15 mg per bulan, atau kira-kira sama dengan 0,4-0,5 mg per hari. Jika jumlah tersebut ditambah dengan kehilangan basal, jumlah total zat besi yang hilang sebesar 1,25 mg per hari.

Responden yang memiliki status gizi lebih gemuk dan mengalami anemia sebanyak 6 dari 8 remaja (75\%). Dari data hasil penelitian didapatkan 6 remaja dengan status gizi gemuk yang mengalami anemia yaitu 5 remaja $(83,3 \%)$ dengan pola menstruasi 8-10 hari dengan rata-rata 9,4 hari. Walaupun remaja tersebut memiliki status gizi gemuk apabila pola menstruasinya tidak normal dapat menyebabkan anemia pada remaja tersebut. Sesuai dengan teori yang dikemukakan oleh Proverawati dan Wati (2011), umumnya wanita yang memiliki siklus menstruasi 2135 hari dan lamanya menstruasi 3-7 hari
Ciptaan disebarluaskan di bawah

Lisensi Creative Commons Atribusi-

NonKomersial-BerbagiSerupa 4.0

Internasional.

menyebabkan banyaknya darah yang keluar dan memengaruhi persediaan zat besi pada tubuh wanita tersebut menjadi rendah dan akan berpengaruh pada kejadian anemia.

\section{Kesimpulan}

Berdasarkan penelitian yang telah dilakukan tentang hubungan status gizi dengan kejadian anemia pada remaja putri di SMP Negeri 2 Garawangi Kabupaten Kuningan maka dapat disimpulkan yaitu terdapat hubungan antara status gizi dengan kejadian anemia pada remaja putri di SMP Negeri 2 Garawangi Kabupaten Kuningan.

\section{Daftar Pustaka}

Almatsier, S. (2009). Prinsip Dasar Ilmu Gizi. Jakarta: Gramedia Pustaka Utama.

Arisman, M. (2014). Buku Ajar Ilmu Gizi: Obesitas, Diabetes Melitus, \& Dislipidemia: Konsep, teori dan penanganan aplikatif. Jakarta: EGC.

Departemen Gizi Dan Kesehatan Masyarakat. (2012). Gizi Dan Kesehatan Masyarakat 2012. Jakarta. Dinas Kesehatan Provisi Jawa Barat. (2016). Profil Kesehatan Provinsi Jawa Barat Tahun 2016. Bandung. Manuaba. (2010). Ilmu Kebidanan Penyakit Kandungan dan Kb. Jakarta: EGC. 
JOURNAL OF MIDWIFERY CARE :

VOL. 01 NO. 02, JUNI 2021

DOI: $\underline{10.34305 / \mathrm{jmc} . v 1 \mathrm{i} 02.266}$

Proverawati, A. S. (2009). Buku Ajar Gizi

Untuk Kebidanan. Yogyakarta: Nuha Medika.

Proverawati, A., \& Wati, E. (2011). Ilmu Gizi Untuk Perawat dan Gizi Kesehatan. Yogyakarta: Yulia Medika. Riskesdas. (2013). Riskesdas RI (Riset Kesehatan Dasar Republik Indonesia), Badan Penelitian dan Pengembangan Kesehatan. Jakarta.

WHO (World Health Organization). (2013).

Worldwide Prevalence of Anemia.

Retrieved from

www.who.int/nutrition/global

_prevalence_anemia/en/pdf
Ciptaan disebarluaskan di bawah

Lisensi Creative Commons Atribusi-

NonKomersial-BerbagiSerupa 4.0

Internasional.

i $i$

